\title{
The Revival of Virtue Ethics As an Ethical View
}

\author{
Chris O. Abakare \\ Department of Philosophy, Nnamdi Azikiwe University, Ifite Road, 420110, Awka, Anambra \\ State, Nigeria \\ Email: chrisabakare@gmail.com
}

(Received: January-2021; Reviewed: February-2021; Accepted: March-2021;

Avalaible Online: March-2021; Published: March-2021)

This is an open access article distributed under the Creative Commons Attribution License

CC-BY-NC-4.0 @2021 by author (https://creativecommons.org/licenses/by-nc/4.0/)

\begin{abstract}
Aristotle and Plato were the chief architects of virtue ethics, but their own formulation of virtue ethics was mostly subdued with the appearance of consequentialism as well as Kantian deontology. However, modem thinkers have attempted to revive virtue ethics in its new form and in this regard the name which is popularly known is G.E.M. Anscombe. In fact Anscombe clearly indicates in what sense virtue ethics can be revived and what was wrong with the traditional virtue ethics as expounded by Aristotle and Plato. Anscombe points out three important issues for which traditional virtue ethics perhaps lost its glory. First, moral philosophy in general cannot survive without an adequate philosophy of psychology and this thing was absent in the traditional virtue ethics. Secondly, without psychological possibility the concepts of moral obligation and moral duty, the moral sense of ought to be jeopardized. Thirdly and importantly, the differences between the well-known English writers on moral philosophy from Sidgwick to the present day are of little importance. This task of this paper is to review the revival of virtue ethics.
\end{abstract}

Keywords: Virtue ethics; moral obligation; moral duty.

\section{INTRODUCTION}

According to Anscombe the philosopher having the conceptual understanding of traditional virtue ethics as well as modern interpretation of virtue ethics can easily realise what are lacking in the traditional virtue ethics as propounded by Aristotle. Very interestingly, the crucial term 'moral' as interpreted by Aristotle cannot find its relevance in modern sense (Anscombe 2011). Aristotle distinguishes virtues as moral as well as intellectuals and what he designates 'intellectual' virtues what we should call a moral. This is so, because a failure of intellectual virtue may be blameworthy. However, this should not be universalized. According to Anscombe, Aristotle confuses the idea of moral blame as if he (Aristotle) conceived the idea of moral blame as opposed to any other, then why has he not considered it more central? For Anscombe, there are some mistakes not of involuntariness in action, but of scoundrels for which 
a man is blamed. Anscombe says, "If someone professes to be expounding Aristotle and talks in a modern fashion about 'moral' such-and-such, he must be very imperceptive if he does not constantly feel like someone whose jaws have somehow got out of alignment: the teeth don't come together in a proper bite" (Darwall 2013, p. 4). Therefore, one should not follow Aristotelian form of virtue ethics, Anscombe opines, in order to formulate a revival form of virtue ethics. He further contends that all the leading ethical thinkers in modern times, from Butler to Mill, lost their glory in the revolution of the revivalism of virtue ethics.

Having been deviated from the contemporary moral philosophy, Anscombe sets out the norms in human virtues. He metaphorically says that just like humans have the teeth, a man to be a virtuous must possess some virtuous qualities. Virtuous quality is not a single one, but there are clusters of qualities which are virtuous qualities. We have already seen that Plato admits four cardinal virtues and many others have considered justice is the prime characteristic of virtue. Anscombe says that just as man has so many teeth, so the species of man just not biologically but from the point of view of the activity of thought and choice in regard to the various departments of life has such and such virtues. Accordingly, a particular man, Anscombe opines, with the complete set of virtues is the 'norm', as 'man' with, e.g. a complete set of teeth is a norm. Here the notion of 'norm' is nearly conceived in the Aristotelian sense rather than a law or legislation conception of ethics as expounded by the deontologists.

It appears that in advocating the revival trend of virtue ethics, Anscombe does not rule out the relevance or influence of external forces or moral luck in considering what is just and what is unjust. This again goes against the standpoint of deontology. Since what is just and what is unjust is relative and one cannot determine it without specifying examples as well as the consequence of the action under consideration, it can be said that what is just in one situation might be unjust in other situation. Consequence of an action plays an important rule in some cases for determining what is just and what is unjust. Now as far as intrinsic unjust is concerned, it can be said that it a procedure is one of judicially punishing a man for what he is clearly understood not to have done, there can be absolutely no argument about the description of this as unjust. No circumstances and no expected consequences can modify the description of it as unjust. Someone who attempted to dispute this would only be pretending not to know what 'unjust' means, for this is a paradigm case of injustice. According to Anscombe in the case so far discussed the term 'unjust' has established the superiority over the term 'morally right' and 'morally wrong'. Moral philosophers since Sidgwick onward discussed whether it might be 'morally right' in some circumstances to adopt that procedure; but this does not make sense to say that the procedure would in any circumstances be unjust.

\section{UNDERSTANDING MORAL OBLIGATION: A NEW OUTLOOK}

Morality being a variety of ethical thought has its own spirit, aims and it implies a general picture of ethical life (Sasa 2019: Okpo 2020). These are said to the genesis of morality which can only be flourished through moral obligation. In fact the term 'obligation' is a general term and it can even be used by the laymen as well, but when we are talking of 'moral obligation', we are thereby specifying a different sort of ethical outlook. The philosopher who was given the purest, deepest, and most through representation of morality is Kant. The new approach of virtue ethics thinks the other way round. It holds that morality is not an invention of philosophers, it is not something compartmentalize, rather morality is the outlook of almost all of us. In the contemporary moral system particularly in the deontological system moral 
obligation is expressed as a kind of deliberative conclusion which is directed towards what to do. Such conclusion is governed by moral reasons and concerned with a particular situation. It is also said that moral obligation is a kind of practical conclusion. It is an obligation to do something with respect to an action known as agent's power. Ought implies can is a formula famous in this connection. The other notable aspect of such morality is that moral obligations cannot conflict with each other, i.e. there is no possibility or chance of moral dichotomy in moral obligations. This leads us to say that what I am obliged to do must be in my power. In this sense, if I am obliged to do X and equally obliged to do Y, then I am obliged to do X and Y. This in fact reflects the practical aspect of the notion of moral obligation.

However, the revival trend of virtue ethics anticipates or rather admits moral conflict in moral obligations which is completely foreign in deontology. Philosopher such as David Ross conceives a terminology for discussing the conflict of obligations. In this regard, he distinguishes between prima facie and actual obligations. A prima-facie obligation is a conclusion supported by moral considerations, which in turn is a candidate for beings one's actual obligation. According to Ross a merely prima-facie obligation can come to support some other actual obligation. If I have for good and compelling reasons broken a promise, I may acquire an actual obligation to do something else because of that it is therefore not clear at all why I should be under this further obligation, because in such a case no actual obligation has been broken for which I should blame myself. In fact I may blame myself for something else such as getting into the situation, but it is mistaken to blame or reproach myself for not doing the rejected action. Does it then make sense to say that moral obligation is inescapable? When one makes a promise, he thereby acquires an obligation voluntarily. Likewise one can make a promise non-voluntarily. In the case of non-voluntary, the person under consideration has no choice of his own.

However, according to the theory of deontology, once I am under the obligation. there is no point of escaping it (Heinzelmann 2018). And the fact that given agent would prefer not to be in this system or bound by its rule will not excuse him nor will blaming him be based on a misunderstanding. Blame is the characteristic reaction for the morality system. However, it is possible for particular agents who belong to the system never to blame anyone in the sense of expressing blame. They might be scrupulously skeptical about what in other people's power. The important point is that self-blame or remorse requires one's action to have been voluntary is only a special application of a general rule that blame of anyone is directed to the voluntary. Unlike the law of an actual liberal republic, the moral law is more exigent as it allows no emigration. In the respect, utilitarianism is a marginal member of the morality system. It may usually think that blame and other social reactions should be allocated in such a way that will be socially useful. This leads us to say that applying the utilitarian criterion to all actions, including the social actions of expressing blame and so forth. However, a utilitarian may ask whether the most useful policy might not be to forget that the point of blame, on utilitarian grounds, was usefulness. Utilitarians are often immensely conscientious people as they work for humanity. They think this is what they morally ought to do and feel guilty if they do not live up to their own standards (Gettell 2019). It is because of such motivations, utilitarianism in most versions is a kind of morality.

The view that moral obligation is inescapable holds that what I am obliged to do is what I must do. It is said to be the first-personal end which even states that moral obligation applies to people even if they do not want to do. The third personal aspect is that moral judgment and blame can apply to people even if they want to live outside that system altogether. In Kant's 
term, we may incorporate these two aspects in saying that moral obligation is categorical (Cummiskey 1990). One way in which the central, deontological, version of morality deals with them is to try to make as many as possible into obligations. In fact William David Ross (2011) lists several types of what he regards as general obligations besides prima-facie obligations. Ross understands general obligations as duties. Prima-facie obligation includes what everyone calls an obligation, keeping promise, telling the truth. General obligations involve 'duties of gratitude', that is to do good to those who have done services for you (Kubala 2020). What Ross is trying to force into the mould of obligation is surely a different ethical idea which he calls 'duties of justice'. According to Ross these duties rest on the fact or possibility of a distribution of pleasure or happiness or the means thereto which is not in accordance with the merits of the persons concerned; in which case there arises a duty to upset or prevent such a distribution. There are such things as duties or obligations of justice and the requirements of justice concern, in the first place, what ought to happen.

However, it is a mistake of morality to comprehend everything in terms of moral obligations. The root, however, is deep. What is ordinarily called an obligation does not necessarily have to win in a conflict of moral considerations. An ordinary moral obligation may at times with suitable cause be evaded, but a stickiest moralist would find a difficulty in the case of moral obligation. In fact obligations have a moral stringency which means that breaking them attracts blame. The only thing that can be counted on to cancel this is that the rival action should represent another and more stringent obligation. Morality encourages the idea, i.e. the idea that only an obligation can beat an obligation. Although morality encourages the idea, but it does not always insist on it, at least in the form that an obligation of mine can be overridden only by another obligation of mine. If some vital interest of mine would have to be scarified in order to carry out a promise, particularly, if the promise were relatively unimportant, even the severest moralist may agree that I would have the right to break the promise, without requiring that I would be under an obligation to do so. Gilbert Harman (1999) in fact raises this point. This is correct, but unless the promise is very trivial, the severe moralist will agree. This suggests an interpretation under which my obligation would indeed be beaten by an obligation, but not one of mine. In insisting that only vital interests count, it is likely that the moralist, when he says that I have the right to safeguard my interest, does not mean simply that I may do that, but that I have what has been called a claim-right to do so. That is to say, others are under an obligation not to impede me in doing so. If this would be the case, then my original obligation will be cancelled by an obligation of the promises, to waive his or her right to performance. Proponents of the revival of the virtue ethics suggest that the dictum that only an obligation can beat an obligation is notoriously a kind of obligation increasingly unrecognized in modern cities.

However, many would like to say that Ross's reductionism, i.e. a prima-facie obligation is ultimately reduced from general obligations would create philosophical trouble. If we adhere Ross's reductionism, then obligation is allowed to structure ethical thought. In order to see around the intimidating structure that morality has made out of the idea of obligation, we need an account of what obligations are when they are rightly seen as merely one kind of ethical consideration among others. This account will help to lead us away from morality's special notion of moral obligation and eventually out of the morality system altogether. Those who are within the morality system usually think that morality is important. Morality by its definition is something to do with personal conduct, something to do with deliberation. Kantian view also locates the importance of morality in the importance of moral motivation itself. Kant tells us that the power of moral law does not lie and could not conceivably lie in anything outside 
oneself. Its power lies in its objective foundation and no experience could adequately represent that kind of objectivity (Singleton 2002). For Kant the moral objectivity comes this, that the requirements of practical reason will be met only by leading a life in which moral consideration play a basic and characteristic role. The sense of reverence for the law holds the key of experience. There is one sense in which the law is rightly represented by the experience as being outside me and it is equally in other people. The moral law is the law of the notional republic of moral agents who are real agents because it is rationally self-imposed by each of the moral agent. For Kant it is the conclusion of practical necessity which locus is deeply inside. What is important is that people should give moral considerations the highest deliberative priority. However, this Kantian view is criticized by Hegel on the grounds that it gives moral thought no content and also it was committed to a double-mindedness about the importance of the world. The content of the moral motivation was the thought of obligation to a certain things as against mere inclination and the need for that thought implied that individual were not spontaneously inclined to do those things. According to Kant morality has an objective foundation and he takes the experience of the moral demand to represent this foundation. However, revival of virtue ethicists seem to have conceived that this view of Kant significantly misrepresents it. In fact, the experience is like a law that is part of the world in which one lives. However, if we deviate from Kant's own account of morality, then we can conceive experience in a different way.

As ethical considerations are in question, the agent's conclusion will not usually be solitary, because they are part of an ethical life shared with others. In this respect the morality system itself, with its emphasis on the 'purely moral' and personal sentiments of guilt and selfreproach, actually conceals the dimension in which ethical life lies outside the individual. Moreover, if we admit that the recognition of obligation is the center of ethical experience, we thereby are building ethical life around an illusion. Revival of virtue ethicists even conceive that even in Kant's own view, this experience involves a misrepresentation. However, if this experience is special only in the psychological mode, i.e. a consequence of transposing objectivity from the transcendental level to the psychological level, then it would be more worse than a misrepresentation. In such a case there would be nothing for it to represent. Kant attempts to show in what sense moral law can be applied unconditionally to all people even though the people under consideration try to live outside it. Those who believe in morality, but disbelieve in Kantian construction would like to say how moral obligation binds those who refuse it. More specifically they would like to say how there can be a moral law at all. In responding to this question, it can be said that just like the law of a state applies to a person because he belongs to a state that just apply power, likewise Kant's moral law applies because as a rational agent or being one had a reason to apply it to oneself. In fact, when we say that someone ought to have acted in some desirable way in which he has not acted, we at times say that there was a reason for him to act in that way. Whatever the reason may be, he has violated the moral obligation. However, in violating or breaking the obligation, he is not necessarily behaving irrationally or unreasonably, but badly. In fact there are many different ways in which people can fail to be what we would ethically like them to be. at one extreme there is a general deliberative incapacity, at another extreme there is sincere as well as capable follower of another creed and besides these there are people with various weaknesses or vices, people who are malicious, selfish, brutal, inconsiderate, self-indulgent, lazy, greedy and all these people can be part of our ethical world. Therefore, there is nothing wrong to say that every ethical world incorporates all these things and any individual life is lined by some of them. Therefore, there are chances of 
many violations of obligations, but blame always tends to share the particularized, practical character of moral obligation in the technical sense.

This would reflect that morality is under too much pressure on the subject of the voluntary actions on the part of moral agents. In fact the blame arising out of institution works coherently, because it attempts less than morality would like it to do. The blame system closely concentrates on the conditions of the particular act and it is surrounded by other practices of encouragement and discouragement, acceptance and rejection, which work on desire and character to shape them into the requirements and possibilities of ethical life. However, the problem with the traditional sense of morality is that it neglects the surrounding and concentrates on the particularized judgment. Therefore, there is a pressure it to require a voluntariness that will be total and will cut through character and psychological and social determination, and allocate blame and responsibility on the ultimate fair basis of the agent's own contribution. This in fact, as suggested by the revivalist of virtue ethics, is an illusion and it is known almost to everyone. The purity of morality conceals not only the means by which it deals with the members of its community but also the virtues of those means.

\section{MORAL STANDARD AND CRITERION OF GOOD LIVING: AN ARGUMENT FOR VIRTUE}

The main objective of any ethical system is to set up at the very outset the criterion or standard of moral living. That is ethicists are keen to reply the question: how should one live? Even Socrates in his own time said that our primary question in moral philosophy is "How should one live?" In Kantian ethics, it is said that the moral standard of one's living should be judged in terms of his moral actions and every moral action as done by a moral agent should be evaluated in terms of moral principles which are absolute in the sense that there is no exception as far as the applicability of the moral principles is concerned (Scharding 2019). Kantian principle of morality is absolute and rigorous as it runs with the moral command: 'duty for duty sake' (Scharding 2019). The problem with Kantianism is that it ignores non-moral qualities, moral lucks on which the moral agent has no control at all. It also ignores many other things a moral agent cannot ignore in maintaining good life. Therefore, the new approach tries to set up a moral standard of living which somehow or other deviates from the philosophical framework of modernity associated with the Kantian ideal of the 'Rational Person'. The concept of free will or the concept of the autonomy of the will rules out any external authority and therefore the self which enjoys free will is alienated from the world.

The new approach therefore seeks a new kind of self which is not alienated from the external authority. The new approach claims that the concepts central to ethics can best be understood if they are first considered in non-ethical contexts. Ethical sphere by no means is separated from the rest of life and it is certainly wrong to conceive morality in terms of rigorosity, autonomy and with the set of contractual arrangements. Ethical sphere is a matter of our whole mode of life and in this regard the practice of learning a language and many other human practices require the exercise of virtues. The language learner, it is said, must exemplify the honesty and the virtue of humility. The new approach holds that the Kantian ideal of the Rational Person fails to incorporate our whole mode of life in the sphere of morality. Therefore, it lacks moral relevance in the context of human life in general. This new approach also tells us that human life has no purpose or telos as many modern moral systems have anticipated. The new approach not only denies Kantian form of modality, it equally tries to make a bridge 
between ancient virtue ethics and the contemporary works on the virtues. It tries to revive the ancient from of virtue ethics with some modifications which are imminent in the context of life.

It is important to point out here that the outlook of moral value has taken a decisive move in the post Kantian moral philosophy. Before Kantianism values were inscribed in the heavens and guaranteed by God. However, in the post Kantian moral philosophy the notion of will, more succinctly the autonomy of the free will, is established as the creator of value. Here the sovereign moral concept is freedom or possibly courage in a sense which identifies it with freedom, will, and power. Act, choice, decision, responsibility, independence are emphasized in this philosophy of puritanical origin and apparent austerity. This image of human nature has been the inspiration of political liberalism. However, Hume tells us that a good political philosophy may not be a good moral philosophy. Whatever the case may be, emotion plays an important part in human life. Kant unlike Aristotle rules out the relevance of emotion in moral life. Aristotle as we find gives sufficient reasons for admitting emotion in the case of morality. Unlike Aristotle, Kant holds an interesting theory about the relation of the emotions to the reason. Kant, we think, did not officially admit emotion in morality, but when he distinguishes between practical love and pathological love, he thereby shows the relevance of emotion. He says that in the case of practical love, there is no scope of emotion as practical love is the outcome of rational actions, but in the case of pathological love, there is the relevance of emotion as pathological love is a mere matter of feeling. This again reflects that Kant makes a clear distinction between empirical psyches from the clean operations of the reason. Moreover, in a "Grundlegung der Erkenntnistheorie" Kant admits a subordinate place to a particular emotion which may accompany the recognition of duty, but in no way motivates duty for the moral law. It is an actual experience of freedom, the realization that although swayed by passions we are also capable of rational conduct- a conduct which is closely related with the Kantian conception of the Sublime (Gruender 1931).

Human's empirical psyche is selfish and Kant wanted to find something clean and pure outside the mess of the selfish empirical psyche. In fact, his enquiry led him back again into the self. Now, defending on the self-defensive psyche, how can we make ourselves better? One may suggest that religion can help us as ordinary man with the simple religious conceptions has usually held a more just view of the matter than the voluntaristic philosopher. Religion normally emphasizes states of mind as well as actions and regards states of mind as the generic background of action, such as, pureness of heart, meekness of spirit (Allam 2018; Edet 2019). More importantly, religion gives rise to devices for the purification of states of mind. For example, prayer can actually induce a better quality of consciousness and can provide energy for good action which would not otherwise be available (Asuquo 2019). In fact by opening our eyes we do not necessarily see what confronts us. We are anxiety-ridden animals. Our minds are constantly active, fabricating an anxious, often falsifying veil which partially conceals the world. Our states of consciousness differ in quality and if quality of consciousness matters, then anything which alters consciousness in the direction of unselfishness, objectivity and realism is to be connected with virtue.

Good life is not exclusively the outcome of reason. Rather it would be the outcome of both experience and reason. Recent moral philosophy denies experience in the case good life, they prefer reason for maintaining a good moral life. However, the new approach thinks the other way round as it holds that experience with beauty plays an important role in maintaining good moral life. Beauty is the convenient and traditional name of something which art and nature share and which gives a fairly clear sense to the idea of quality of experience and change 
of consciousness. According to Plato beauty is the only spiritual thing which we love by instinct and when we move from beauty in nature to beauty in art we are already in a more difficult region. In fact the experience of art is more easily degraded than the experience of nature (Ramos 2019). A great deal of art actually is self-consoling fantasy and even great art cannot guarantee the quality of its consumer's consciousness. However, great art exists and is sometimes properly experienced and even a shallow experience of what is great can gave its effect. In fact great art invigorates our best faculties or more specifically in Platonic language, it inspires love in the highest part of the soul. Since art is a human product, virtues and talents are required of the artist. A good artist in terms of his art is brave, truthful, patient and humble. The enjoyment of art is a training in the love of virtue. Art transcends selfish and obsessive limitations of personality and the true genesis or realism of a great artist is not a photographic realism, rather it is essentially both pity and justice.

According to the new approach the only thing which is of real importance is the ability on the part of moral agent to foresee it all clarity and respond to it justly which is inseparable from virtue. Perhaps, one of the greatest achievements of all is to join this sense of absolute morality, not the tragic, but to the cosmic. Art therefore stands not as a division, rather it is the most educational of all human activities and intuits a place in which the nature of morality can be seen. Art pierces the veil and gives sense to the notion of a reality which lies beyond appearance. It exhibits virtue in its true guise in the context of death and chance. According to Plato beauty, a kind of virtue could be a starting point of good life. He, however, mistrusts art as for him all art is bad art, a mere fiction and consolation which distorts reality. As far as virtue is concerned, it can be said that virtue is a good habit and dutiful action and the background condition of such and such action is a just mode of vision and a good quality of consciousness. It is a task to come to see the world as it is. A philosopher who leaves duty without a context and exalts the idea of freedom and power as a separate top level value ignores this task and obscures the relation between virtue and reality. However, we act rightly not out of strength of will but out of the quality of our usual attachments and with the kind of energy and discernment which we have available and to this the whole activity of our consciousness is relevant.

One may attempt to give a logical answer of the term Good. For them asking what Good is, is asking what truth is or what courage is. If we define Good as X, we thereby mean of course a good X. In this regard, if we say that Good is Reason, we have to talk about good judgment and if we say that Good is Love, we have to explain that there are different kinds of Love. All things which are capable of showing degrees of excellence show it in their own way. That means to say that the idea of perfection can only be exemplified in particular cases in terms of the kind of perfection which is appropriate. However, the point is that although one can talk about good painting, but one could not say in general what perfection is. One can talk about good judgment, but the truth of judgments of value cannot be demonstrated. This actually indicates or suggests that the view of Good is empty and almost trivial. The indefinability of Good is connected with the unsystematic and inexhaustible variety of the world and the pointlessness of virtue. In this respect there is a special link between the concept of Good and the ideas of death and chance. A genuine sense of morality enables us to see virtue as the only thing of worth and it is impossible to limit and foresee the ways in which it will be required of us. Good is mysterious, because of human fatality. We behave well in areas where this can be done fairly easily and let other areas of possible virtue remain undeveloped. There are few places where virtue plainly shines and we without improving ourselves cannot see these things. It is in the context of such limitations that we should picture our freedom. Freedom is a mixed 
concept. It is mixed in the sense that it has true half as well as false half. Its true half is an aspect of virtue connected especially with the clarification of vision and the domination of selfish impulse and its false half known as popular half is a name for the self-assertive movements of deluded selfish will, which because of our ignorance we take to be something autonomous.

What has been said above is made clear with the following observation of Plato. Plato has given up the image of deluded worship in his great allegory (Giannopoulou 2011). The prisoners in the cave at first witness the back wall and behind them a fire is burning in the light of which they see upon the wall the shadows of puppets which are carried between them and the fire. They take these shadows to be the whole of reality. When they turn around they can see the fire, which they have to pass in order to get out of the cave. Here the fire is just like the self, the old unregenerate psyche, the great source of energy and warmth. The prisoners in the second stage of enlightenment have gained the kind of self-awareness, which is nowadays a matter of so much interest to us. They can see in themselves the source of what was formally blind selfish instinct. They see the flames which threw the shadows which they used to think were real, and they can see the puppets, imitations of things in the real world, whose shadows they used to recognize. They do not yet dream that there is anything else to see. What is more likely than that they should settle down beside the fire, which though its form is flickering and unclear is quite easy to look at and amusing to sit by? It has been said that good is indefinable. However, philosophers have attempted to conceive Good by making a special relation with other concepts, such as, Freedom, Happiness, and Courage etc. But the problem with this conceivability is that they seem to represent in each case the philosopher's admiration for some specialized aspect of human conduct which is much less than the whole of excellence and more importantly at times dubious in itself. One may be tempted to say that what is Good is love, but the problem with this interpretation is that Good and Love should not be identified, because human love is usually self-assertive. Although Good is sovereign over Love, they still play different roles. Good is the magnetic centre towards which truth or reality is not the outcome of abstract intellect modern moralists thinks of but of looking and seeing around us. This views of moral perception has its roots in Aristotle's accounts of practical wisdom of the virtuous man who sees the things as they are and responds appropriately. The good therefore brings unity in to the world of chaos and this is made possible of course partly through the understanding we can have of the relationship between hierarchies in the virtues. However, this understanding has to be complemented by an awakener of the richness and complexity of details in everyday situation an awareness itself grounded in the life of good.

\section{THE SCHIZOPHRENIA OF MODERN ETHICAL THEORIES}

Philosophers belonging to the revival camp of virtue ethics are of the opinions that modern ethical theories have suffered from schizophrenia (Barry 2016). Moral schizophrenia is a kind of moral malady and one can witness various kinds of moral maladies in modern ethical theories. With a few exceptions modern ethical theories such as consequentialism as well as deontology deal only with reasons. As a matter of fact they fail to incorporate motives and the motivational structures and constraints of ethical life. Ethical theories based on reasons but forfeiting motives would not enable to produce good moral life. It is contended that one inevitable mark of a good life is to make a harmony between one's motive and one's reasons, values and justification. Therefore, to make split between one's motives and one's reasons is properly called a moral schizophrenia. In fact, an extreme form of such schizophrenia is 
characterized by being moved to do what one believes bad, harmful, ugly, abasing on the one hand and by being disgusted, horrified, dismayed by what one wants to do on the other. It is important to note here that a good life cannot be conceived without motives as our major values through which a good life can be attained are intimately associated with our motives (Balsemão Pires 2020). More succinctly, it can be said that we should value what our major motives seek.

A good life is a mark of harmony - a moral integration without which human life, good or bad, is not possible. This does not, however, lead us to say that in all cases moral harmony is better to have; rather it would better for us if self-seeking authoritarians adopt the reason of their motives. It is also not to be the case that in all areas of endeavour moral harmony is necessary for achieving moral value. For them motives is irrelevant as far as rightness, duty and obligatoriness are concerned. However, revivalists of virtue ethics would like to say that although rightness, obligatoriness and duty are without harmony, but there is still a question of harmony. What sort of life would people have who did their duties but never wanted to? Secondly, duty, obligation and rightness are only one part, a small part of ethics. In fact, there is the whole other areas of values of personal and interpersonal relations and activities and also the areas of moral goodness, merit and virtue where motive is an essential part of what is valuable. This leads us to say that in both these cases motive and reason must be in harmony for the values to be realised. Therefore, no one can deny that the view that moral harmony is a mark of a good life. The modern ethical theories fail to give rise to a good life as such theories make harmony impossible.

Thus, a good life in the true sense can only be provided by the renewal or revival trend of virtue ethics. Why is it called revival? It is called revival in the sense that ethics stats with virtue ethics as propounded by Aristotle and Plato. Subsequently, it has lost its ground with the appearance of consequentialism and deontology. However, some philosophers with sufficient grounds have realised that a good life can only be attained by reviving virtue ethics and this can be made possible by making it clear that modern ethical theories cannot survive any more with the concept of duty, obligations. The problem of modern or recent ethical systems is that they have over concentrated on moral duty, rightness and obligations while reflecting on the complexity and vastness of our moral life. This is not only their failure; besides this they also make a mistake by forfeiting the relations of motives to values. In the second failure virtue revivalists conceive a far more serious defect of modern ethical theories than such over concentration on duty, obligation and rightness. The interlinked between motive and reason is overlooked in modern ethical theories which according to the virtue revivalists is vital as far as understanding of morality is concerned. In fact it is the pervasive area of value. More succinctly, it can be said that by ignoring the moral association between motive and reason, modern moral theories allow us the harmony of a morally impoverished life which is deeply deficient in what is valuable instead of a morally good life. Therefore, it is not possible for people to achieve value, to act on these ethical theories, to let them comprise their motives. In fact people who do let them comprise their motives will have a life seriously lacking in what is valuable. Therefore, it is assumed that modern moral theories are defectively in more then one ways. As ethical theories they fail to provide the moral agents the good or good life in an integrated way. As theories of the mind, of reasons and motives, of human life and activity, they fail, not only by putting us in a position that is psychologically uncomfortable, difficult, or even untenable, but also by making us and our lives essentially fragmented and incoherent. There is no question of doubt that loving, caring, compassion, friendship, affection, fellow feeling, and community or society or broadly speaking our environment or surroundings are the important sources of 
person pleasure. If this would be the case, then can we say that a typical hedonistic egoist can get these pleasures? Certainly he would not get such pleasures as he adheres to the motive of pleasure for self. This, of course, does not mean that egoists cannot get together and decide to enter into a love relationship. Rather they surely like other can and they equally can do various things to bring about such pleasure. Nonetheless there is necessarily something lacking in such a life which is unlikely ion the life of a virtuous being. That means whatever the attempt an egoist happens to make, the sense of loving is missing in his life which is unlikely in the case of a virtuous being.

Virtue ethics in its form attempts to provide an untroubled life which is personally pleasurable to every one possessing virtuous (Abakare 2020). However, the approach of an egoist is different from a virtuous being. He thinks the other way round. For him a life is good which is personally pleasurable to him alone and accordingly he acts in various ways towards others with the final goal of getting pleasure for himself alone. This leads indirectly that he does not act for others. This further confirms why egoism is often claimed to be essentially lonely. A relevant question comes into being here. What would be the case if an egoist is transformed into a non-egoist and thereby acquiring the virtue of caring for others? In responding this question it is said that by way of transforming an egoist into a non-egoist, the concerned person by acquiring the virtue of caring for others loses conscious control on him as an egoist. The question again arises: can an egoist by acquiring the virtue of caring for others will be able to cheek up and see how his transformed self in getting on in achieving egoistically approved goals. Will they have a mental alarm clock which in fact wakes them up from their nonegoistical transforms every in a while? It is really difficult to give a clear cut reply without question begging. However, what is bad enough to have a private personality which every now and then encourages one to hide from others alienates one from others. Therefore, it is concluded by saying that egoism in general is defected.

According to utilitarianisms an act is right, obligatory if and only if it is optimistic in regard to pleasure and pain and only good reason for acting is pleasure vs. pain (Gibbard 1973). Accordingly, whatever your relation to that person, it is necessarily not love, nor is it friendship, affection, fellow feeling and community. Here the person you supposedly love engages your thought and action not for him, but rather as source of pleasure. If you try to carry on the relationship for the sake of goodness, there is no essential commitment even to that activity. So far as goodness is concerned, one cannot ignore love, i.e. the good of love. Accordingly, any person who would elicit as much of this good would be a proper an object of love as the beloved. The theory tells us to bring about this good, but now we do foresee that we cannot separate what is good, the love from its goodness. This leads us to say that just as egoism; utilitarianisms in various types necessitate schizophrenia between reason and motive as they cannot allow for love, friendship, affection, fellow feeling, and community. Thus, schizophrenia is equally found both in rule utilitarianisms as well as in the current deontology.

What is simply absent in these current theories is simply the person, the character. For love, friendship, affection, fellow felling and community that require that the other person be an essential part of what is valued. The person must be valued. The defect of the current moral theories is that in regard to love is not that they do not value love, but that they do not value the beloved. A person who values and aims at simply love or love in general misses the intended beloved. Modern ethical theories would prevent each of us from loving, caring for, and valuing oneself as opposed to loving, caring for, and valuing our general values. In these externallyridden theories, there is as much a disappearance non-appearance of the self as of other people. 
In fact, their externality-ridden universes of what is intrinsically valuable are not solipsistic; rather, they are devoid of all people. Moore's taking friendship is to be an intrinsic good is an exception here. However, if the previous criticism of Moore holds, his so taking friendship introduces serious strains, verging on inconsistency, into his theory. Egoism, in fact, puts people in vulnerable position. It treats humans externally or as mere instruments and truly speaking these ways are dehumanising. Therefore, to say much more than this would require a full-scale philosophical anthropology showing how such personal relations as love and friendship are possible, how they relate to larger ways and structures of human life. Therefore, virtue ethics of the revival form always insists for the development of those relations which are constitutive of human life worth living. More importantly, it looks at how the fullness of good life, a life of eudaimonia in Aristotelian sense, is made possible.

Now the question is: what sort of motives people can have if they are to be able to realise the great goods of love, friendship, affection, fellow feeling, and community. Love, friendship, affection, fellow feeling, and community essentially contain like many others states and activities certain motives and essentially preclude certain others and among those precluded we find motives comprising the justifications, the goals, and the goods of those ethical theories prominent today. As a matter of fact current ethical theories treat people externally and to preclude love, friendship, affection, fellow feeling, and community both with others and with oneself. Therefore, to have these great goods while holding those current ethical theories requires schizophrenia between reason and motive. The problem with the prominent current ethical theories is that if you hold or live the theories directly, you will fail to achieve its goal. Thus, charges of disharmony, moral cleavage, schizophrenia are being maid against the current moral theories where the personal relationship of love, friendship, affection, fellow feeling and community are hard to come by. These qualities are essential to make a man as true man, a true virtuous being. These are also said to be the pyramid of human character through which a person enjoys a good life. A special case can be cited here to make the point clear. Suppose you have been locked up in a psychiatrist hospital and are naturally most eager to get out. Incidentally you ask the psychiatrist when you will be released. He replies, "Pretty soon". You further find out that instead of telling patients what he really believes, he tells them what he believes is good for them to hear. Perhaps you could 'crack his code' by discovering his medical theories and his beliefs about you. It might be expected that in such case explicitly concerned with motives and their evaluation, ethical theories would not lead us into this disharmony or the corresponding morally defective life. Even in regard to moral merit and demerit, the moral virtues and vices, the situation is not wholly dissimilar. The standard view tells us that a morally good intention is an essential constituent of a morally good act. A morally good intention is an intention to do an act for the sake of its goodness or rightness. But now suppose you are in a hospital recovering from a long illness. You are very bored and restless and at loose ends when Smith comes in once again. You are now convinced more than ever that he is a fine fellow and a real friend-taking so much time to cheer you up, traveling all the way across town, and so on. However, it reveals at the end that it is not essentially because of you that he came to see you, not because you are friends, but because he thought it his duty or simply because he knows of no one more in need of cheering up and no one easier to cheer up.

\section{CONCLUSION}


It has been observed that recent moral theories are concerned entirely with rightness, obligation and duty, but not with the whole of ethics. On the basis of the above observation, it is perhaps clear enough by now that recent ethicists have ignored largely and extremely important areas of morality, such as personal relations and that of merit. It the proponents of such ethical theories believe that duties, obligations and so no really the whole, then they were mistaken about the scope and importance of duty and so on. They were mistaken about these concepts as even a brief study of supererogation and self-regarding notions would indicate. Secondly, these theories are dangerously misleading as they all too readily be taken as suggesting that all of ethics can be treated in an external, legislation-model, index way. Thirdly, the acceptance of such theories as partial theories would pose severe difficulties of integration within ethical theory. As these theories are so different from those concerning personal relations, how are they all to be integrated? This would reflect how contemporary ethical theories come to require either a stunted moral life or disharmony, schizophrenia. As far as moral legislation is concerned, they were concerned with duty, rightness, and obligation. When viewing morality from such a legislator's point of view, when adopting such legislation to be the model, ethical motivation appears to be irrelevant and more importantly where there is moral legislation there is also tied up with a general devaluing of our emotions and emotional possibilities. All these things discussed above may help us to answer a question why contemporary ethical theories suffer from schizophrenia, bifurcation, and disharmony.

\section{REFERENCES}

Abakare, C. (2020). The Origin Of Virtue Ethics: Aristotle's Views. GNOSI: An Interdisciplinary Journal of Human Theory and Praxis, 3(1), 98-112.

Allam, O. S. (2018). Unmasking "Alekwu" Religious Experience among the Idoma PeopleGroup of Nigeria. GNOSI: An Interdisciplinary Journal of Human Theory and Praxis, 1(2), 118-130.

Anscombe, G. E. M. (2011). Human life, action and ethics: essays by GEM Anscombe (Vol. 4). Andrews UK Limited.

Asuquo, O. O. (2019). Humanism as a Category of Religious Alternative. GNOSI: An Interdisciplinary Journal of Human Theory and Praxis, 2(1), 30-36.

Balsemão Pires, E. (2020). Counselling and Ethical Theories. Acta Europeana Systemica, 8, 315-326. https://doi.org/10.14428/aes.v8i1.56503

Barry, P. (2016). Schizophrenia and the Virtues of Self-Effacement. Les Ateliers de L'éthique, 11(1), 29-48. https://doi.org/10.7202/1038197ar

Cummiskey, D. (1990). Kantian Consequentialism. Ethics, 100(3), 586-615. https://doi.org/10.1086/293212

Darwall, S. (2013). Honor, history, and relationship: Essays in second-personal ethics II. OUP Oxford.

Edet, F. F. (2019). The concept of worship in Islam. Lwati: A Journal of Contemporary Research, 16(4), 125-130.

Gettell, R. G. (2019). The English Utilitarians. In History of Political Thought (pp. 340-355). https://doi.org/10.4324/9780429270550-21 
Giannopoulou, Z. (2011). Plato and the Question of Beauty. Ancient Philosophy, 31(2), 412416. https://doi.org/10.5840/ancientphil201131230

Gibbard, A. (1973). Doing no more harm than good. Philosophical Studies, 24(3), 158-173. https://doi.org/10.1007/BF00367993

Gruender, H. (1931). Grundlegung der Erkenntnistheorie. Thought: Fordham University Quarterly, 6(1), 125-130.

Harman, G. (1999, January). Moral philosophy meets social psychology: Virtue ethics and the fundamental attribution error. In Proceedings of the Aristotelian society (pp. 315-331). Aristotelian Society.

Heinzelmann, N. (2018). Deontology defended. Synthese, 195(12), 5197-5216. https://doi.org/10.1007/s11229-018-1762-3

Kubala, R. (2020). Aesthetic obligations. Philosophy Compass, 15(12), 1-13. https://doi.org/10.1111/phc3.12712

Okpo, O. (2020). Nigeria's Traditional Virtue Ethics and Business: An Ibibio Virtue Ethics Approach to Business Ethics. GNOSI: An Interdisciplinary Journal of Human Theory and Praxis, 3(1), 16-31.

Ramos, S. (2019). Plato and Kant on Beauty and Desire. Epoché: A Journal for the History of Philosophy, 24(1), 1-26. https://doi.org/10.5840/epoche20191010142

Ross, W. D. (2011). Foundations of ethics. Read Books Ltd.

Sasa, M. S. (2019). An Appraisal of the Concept of Beauty in Immanuel Kant's Philosophy. GNOSI: An Interdisciplinary Journal of Human Theory and Praxis, 2(2), 87-97.

Scharding, T. (2019). Individual Actions and Corporate Moral Responsibility: A (Reconstituted) Kantian Approach. Journal of Business Ethics, 154(4), 929-942. https://doi.org/10.1007/s10551-018-3889-z

Singleton, J. (2002). Virtue ethics, Kantian Ethics, and Consequentialism. Journal of Philosophical Research, 27, 536-551. https://doi.org/10.5840/jpr_2002_16 
Chris O. Abakare; The Revival of Virtue Ethics As an Ethical View ... 299 